\title{
Toxicity and Antimetabolic Properties of Biologically Treated Neem Seed (Azadiracta indica) Kernel Cake
}

\author{
Mubarak O. Ameen ${ }^{1, *}$, Moshood A. Belewu ${ }^{2}$, Lamidi A. Usman ${ }^{1}$, Oladoyin O. Onifade ${ }^{1}$, \\ Sophia O. Adetutu ${ }^{1}$ \\ ${ }^{1}$ Department of Chemistry, University of Ilorin, Ilorin, 240001, Nigeria \\ ${ }^{2}$ Department of Animal Production, Microbial Biotechnology and Dairy Science Laboratory, University of Ilorin, Ilorin, 240001, Nigeria \\ aommohd@yahoo.com
}

\begin{abstract}
Seeds from Neem plants were ground and defatted to obtain the meal, the neem seed cake (NSC). The seed cake was fermented with two different fungi Aspergillus niger and Mucor mucedo. Proximate compositions as well as antinutrient factor of the treated cakes were analyzed. The results obtained reveals that the defatted Neem seed cake treated with $A$. niger contains protein of $47.70 \%$ which is higher than the seed cake treated with $M$. mucedo and the untreated sample. The untreated sample which is the control contains more dry matter and crude fiber of $80.67 \%$ and $0.51 \%$ respectively. It was also observed that the sample treated with $A$. niger contains more phytate and tannin of $7.95 \%$ and $1.30 \%$ respectively. Though the treatment has increased the crude protein content of Neem seed cake, but the biological treatment may not be suitable for the detoxification of neem seed cake as the antinutrient factors (oxalate, phytate, tannin and cyanide) determined were significantly higher in the treated than the untreated seed cake.
\end{abstract}

Keywords Neem Seed Cake, Aspergilus Niger, Mucor Mucedo, Antinutrients

\section{Introduction}

Several attempts have been made to find solutions to nutritional problems in Africa in relation to protein intake. Interest in newer sources of protein has grown due to protein shortage in developing countries, especially Nigeria. As part of the quest for newer sources, some lesser-known oil seeds have been evaluated for their nutritional qualities in India[1-5]. In Nigeria, locally available but unusual proteins containing foodstuffs have been evaluated for their nutritional potentials, aiming at reducing dependence and competition between livestock and man for the consumable sources[6-8].

Neem (Azadirachta indica), is an evergreen tree which is endemic to the Indian subcontinent and has been introduced to many other areas in the tropics[9]. The tree is known to cure more than one hundred diseases. Neem seed cake (NSC) is a by-product showing great potential for livestock feeding $[10,11]$, NSC meal is a protein rich source (CP: $34-38 \%$ ), the protein in the cake is relatively balanced in its amino acid and mineral profiles[12,13].

Despite the high nutritional value of NSC especially for livestock, its bitter taste and foul odour limits its use as a food source,[14]. The bitter taste of neem seed is as a result

* Corresponding author:

aommohd@yahoo.com (Mubarak O. Ameen)

Published online at http://journal.sapub.org/chemistry

Copyright (C) 2012 Scientific \& Academic Publishing. All Rights Reserved of the presence of sulphur containing compounds, while the tignic acid is the main compound believed to be responsible for its odour,[15,16]. Consequently, the cake has been treated by various methods, including water washing[11], urea treatment[10] and solvent treatment[17-19]. Similarly, Regional Research Laboratory, Hyderabad in India has developed a simple extraction process of removing toxic compounds. When Udayashekara employed this process on neem seed, the seed was devoid of the bitter taste and its usual foul smell while retaining its nutritional value[14]. In another work Usman et al has attempted the extraction of protein from the neem seed[20]. This work thus aims at studying the effects of biological treatment (Aspergillus niger and Mucor mucedo) to inactivate the antinutrional factors in Neem Seed Cake.

\section{Experimental}

\subsection{Preparation of Neem Seed Cake}

The seeds were obtained from ripe fruits harvested from different locations in Ilorin, Nigeria. The exocarp and pulp of the riped fruit was removed and the endocarp was oven dried at $60^{\circ} \mathrm{C}$. The dried endocarp was cracked to obtain the seed. The seeds were milled using magic blender (SHB - 515 model made by Sorex Company Limited, Seoul Japan) to obtain the seed cake. Standard Official and Tentative Method of Association of Official Analytical

Chemists procedure was used to defat the seed cake[21]. 
The defatted seed cake was dried and kept for analysis. The cake was autoclaved using an autoclaving machine set at a temperature of $121^{\circ} \mathrm{C}$ for 30 minutes in the laboratory of the Department of Biochemistry University of Ilorin, Ilorin.

\subsection{Preparation and sub- culturing of the Fungi}

The fungi (Mucor mucedo and Aspergillus niger) were obtained from the laboratory of the Department of Microbiology, University of Ilorin, Ilorin.

A paste of Potato Dextrose Agar (PDA) was prepared by weighing $10 \mathrm{~g}$ of PDA in $250 \mathrm{ml}$ of distilled water; it was then autoclaved (Autoclave machine model YSQ-LS-/00SII) at $121^{\circ} \mathrm{C}$ at $15 \mathrm{lbs}$ per square inch for 15 minutes. It was allowed to cool to about $45^{\circ} \mathrm{C}$ and streptomycin injection was added. The mixture was then poured into a sterile plate and allowed to set (solidify), after setting, the required organism was inoculated into the plate and incubated at room temperature for 72 hours. A pointed needle was used to pick the organism from the stock and stab the center of the plate.

\subsection{Inoculation and Incubation of Neem Seedl cake}

The autoclaved cake was divided into three portions, a portion was inoculated with Aspergillus niger (treatment A) another Mucor mucedo (treatment B) while the third was left untreated (Control experiment). All the treatments were inoculated at ambient temperature in the laboratory. The fungal growth was terminated after 10 days by oven drying the spent substrates in an air draught oven at $70^{\circ} \mathrm{C}$ for 24 hours in the laboratory of the Department of Animal Production, Faculty of Agriculture, University of Ilorin.

\subsection{Analyses}

The proximate compositions of the fermented samples were analyzed using the method of AOAC[21]. All data were analyzed using ANOVA of a completely randomized design model.

\section{Results and Discussions}

Neem seed cake can be a source of protein for animal feed if the cake is properly treated to remove the antinutritional principles in the seed. This work attempted the improvement of the nutritional quality of the neem seed cake using biological treatment method. Table 1 present the proximate composition of fungi treated and untreated neem seed cake.

The results presented in Table 1 shows the effect of the biological treatment on the dry matter, ether extract, crude fibre, ash content and crude protein contents of neem seed cake. The results clearly indicate that the treatment reduces the dry matter, crude fibre and ash content of the neem seed cake, while the ether extract was drastically increased. There was on the other hand an increase in the crude protein of the A. niger but a decrease in the M. mucedo treated cakes, Table 1. These observations are similar to those of
Belewu \& Sam and Belewu M. A. who also treated Jatropha curcas kernel for nutritional improvement biologically[22-23].

Table 1. Proximate Composition of Fungi Treated and Untreated Neem Seed Cake

\begin{tabular}{|c|c|c|c|c|}
\hline Parameters & Control & $\begin{array}{c}\text { Aspergillus niger } \\
\text { treated sample }\end{array}$ & $\begin{array}{c}\text { Mucor mucedo } \\
\text { treated sample }\end{array}$ & \pm SEM \\
\hline Dry matter & 80.67 & 40.00 & 47.00 & 37.39 \\
\hline Ether extract & 3.50 & 52.50 & 26.50 & 9.04 \\
\hline Crude fibre & 0.51 & 0.11 & 0.14 & 0.055 \\
\hline Ash content & 14.00 & 8.00 & 10.50 & 12.56 \\
\hline Crude protein & 41.30 & 47.70 & 24.10 & 40.22 \\
\hline
\end{tabular}

Key: + means of three rdeterminations; $\mathrm{SEM}=$ Standard error of the mean

Table 2. Antinutritional factors of fungi treated and untreated Neem seed cake $^{+}$

\begin{tabular}{|c|c|c|c|c|}
\hline Parameters & Control & $\begin{array}{c}\text { Aspergillus niger } \\
\text { treated sample }\end{array}$ & $\begin{array}{c}\text { Mucor mucedo } \\
\text { treated sample }\end{array}$ & \pm SEM \\
\hline Oxalate & 0.54 & 1.08 & 1.62 & 3.635 \\
\hline Phytate & 6.41 & 7.95 & 6.92 & 3.636 \\
\hline Tannin & 1.10 & 1.30 & 1.20 & 3.635 \\
\hline Cyanide & 0.675 & 0.675 & 0.675 & 3.635 \\
\hline
\end{tabular}

Key: + means of three determinations; SEM $=$ Standard error of the mean

Table 2 presents the antinutrient factors in the treated and untreated neem seed cake. The oxalate, phytate, tannin and cyanide were determined. From the results obtained it is clearly shown that the biological treatment may not be suitable for the detoxification of neem seed cake as the factors determined were significantly higher in the treated than the untreated seed cake, Table 2.

\section{Conclusions}

Various methods has been described for the treatment of neem seed cake so that it could be useful in animal feeds, this attempt at using biological treatment for the detoxification of neem seed cake was not successful as the antinutrional factors in the treated cakes were significantly higher than the untreated cake. Thus it can be concluded that $A$. niger and $M$. mucedo may not be suitable for the treatment of neem seed, however treatment with other types of fungi may give positive results or other treatments can be improved upon.

\section{REFERENCES}


[1] Udayashekhara RP, Belavady B (1979). Chemical composition and biological evaluation of Goa beans (Psophocarpus tetragonolobous) and their tubers. J. Plant Foods 3: 169-174.

[2] Udayashekhara RP (1991). Nutrient composition and biological evaluation of defatted tomato (Lyeopersicum esculentus) Seed Cake. Plant Foods Hum. Nutr. 41: 101-106.

[3] Udayashekhara RP (1994). Nutrient composition of some less familiar oil seeds, Food Chemistry 50: 379-382.

[4] Rukmini C, Udayashekara RP (1986). Chemical and nutritional studies on Terminalia bellirica Rob kernel and its oil. JAOC 36: 360-363.

[5] Vijayakumari K, Siddhuraju P, Janardhanam K (1994). Nutritional assessment and chemical composition of the lesser known tree legume Aeoeia leucophloea. (Roxb), Food Chem. 50: $285-288$.

[6] Fetuga, B. L.; Babatunde, G. M. and Oyenuga, V. A, (1974), Protein quantity of some unusual foodstuff: Studies on the African locus-bean seed (Parkia Fullcoidea Welw). Bi. J. Nutr. 32: 27-36.

[7] Mba AU, Njike MC, Oyenuga VA (1974). The proximate chemical composition and the amino acid content of Nigerian oil seeds. J. Sci. Food Agric. 25:1547-1553.

[8] Oyenuga VA, Fetuga BL (1975). Some aspects of the biochemistry and nutritive value of the watermelon seed (Cittrullus Vulgaris Schrad) J. Sci. Food Agric. 26: 843-854.

[9] Rajeev S. (2009), Dinkal Agro Inc: Organic for Healthy Living, Dehra Dun, India: International Book Distributors. Pp123 - 128.

[10] Musalia, L. M.; S. Anandan, V. R. B. Sastry and D. K. Agrawal, (2000) Urea-treated neem (Azadirachta indica) Seed kernel cake as a protein supplement for lambs, Small Ruminant Res. 35: 107 - 116.

[11] Rao, V. K.; Kowale, B. N. and Verma, A. K. (2002), Effect of feeding water washed neem (Azadirachta indica) seed kernel cake in the quality, lipid profile and fatty acid composition of goat meat, Small Ruminant Res. 47: 213 -219.

[12] Gowda, S. K. and Sastry, V. R. B. (2000), Neem (Azadirachta indica) seed cake in animal feeding, scope and limitation, Rev. Asian-Aus. J. Anim. Sci. 13: p. 5.

[13] Bawa, G.S., M. Orunmuyi and O.A. Onabanjo, (2005)Effect of dietary inclusion levels of mechanically extracted neem seed cake onperformance of young rabbits. Nig. J. Anim. Prod., 32: 233 - 239.

[14] A.A. Odunsi, S.A. Adegbile, T.O. Akande and T.B. Olayeni, (2009) Neem (Azadirachta indica) Seed Cake in the Diets of Cockerel Chickens, International Journal of Poultry Science 8 (1): $47-51$.

[15] Udayashekhara RP (1987). Chemical composition and biological evaluation of debitterised and defatted neem (Azadirachta indica) Seed Kernel Cake. J. AOCS 64: 1348-1352.

[16] Karkar, C. N. (1976). Utilization of neem (A. indica) and its by-products: Report of the modified neem cake manurial project 1969-76. Directorate of non-edible oils soap industry Khadi and village industries commission, 3, lria Road, Vile. Park (west), Bombay, India.

[17] Raman, H. and Santhanagopalan, S. (1979). Indian J. Chem. Biorg. Ind. Med. Chem. 17: 169 Cited in: MM IWU (1993). Handbook Afri. Medicinal plants. CRC Press London, pp. 124-128.

[18] Chad, S. (1987), Nutritional evaluation of neem seed meal in chicks, PhD Thesis, Rohilkhand Univ. Bareilly, Indian, pp. 66-106.

[19] Reddy, V. R. and Rao, P. V. (1988), Utilization of chemically treated neem cake in broilers. Indian J. Anim. Sci. 58: 958-963.

[20] James, D. B.; Ameh, D. A. and Agbaji. A. S. (2007), Proximate composition of seed of Azadirachta indica (Dogonyaro) and the extraction of its protein. Nig. J. Bioc. Mol. Biol. 5: $75-78$.

[21] Usman, L. A., Ameen O. M., Ibiyemi S. A. and Muhammad, N. O. (2005), The extraction of proteins from the neem seed (Indica azadirachta A. Juss), African Journal of Biotechnology Vol. 4 (10), pp. 1142 - 1144.

[22] AOAC (Association of Official Analytical Chemists). 1990. Official Methods of Analysis (15th edn). AOAC: Washington DC.

[23] Belewu, M. A. (2008), Replacement of fungus treated Jatropha kernel meal for soybean meal in the diet of rats, Green Farming, 2(3): $154-157$.

[24] Belewu, M. A. and Sam, R. (2010), Solid state fermentation of Jatropha curcas kernel cake: Proximate composition and antinutritional components, Journal of Yeast and Fungal Research, 1(3), $44-46$. 